\title{
MODERN SUBMISSION OF FORMATION, COMPOSITION AND ROLE OF ORAL (DENTAL) BIOFILM IN DEVELOPMENT OF PERIODONTAL DISEASES
}

DOI: 10.36740/WLek202008132

\author{
Maria 0. Stetsyk, Andriy 0. Stetsyk, Natalia I. Zhero, Eugene Y. Kostenko, Svetlana B. Kostenko, Ilya D. Pirchak
}

UZHHOROD NATIONAL UNIVERSITY, UZHHOROD, UKRAINE

\begin{abstract}
The aim: To investigate current trends in the study of oral biofilm and its control.

Materials and methods: A research of 32 literature sources has been made and it has been taken into account that some terminological differences in determining objects of study. Conclusions: Detailed analysis of modern domestic and foreign literature argues the necessity of further in-depth study of oral biofilms. Understanding the ethiological factors and mechanisms of the pathogenesis periodontal tissues inflammatory diseases gives the opportunity to treat targetly by destroying complicated sections of the vital activities and oral biofilm microorganisms relationships.
\end{abstract}

KEY WORDS: oral microbiome, biofilm, dental plaque, periodontal pathogens, QS - system

Wiad Lek. 2020;73(8):1761-1764

\section{INTRODUCTION}

Recent years research confirm the high relevance of nature study and properties of oral biofilm (dental plaque) as one of the main factors in the oral cavity biological balance and the possible factors of its disturbance resulting in various inflammatory diseases of the oral cavity.

\section{THE AIM}

To investigate the level and tendencies scientific knowledge development about oral biofilm and its management based on domestic and foreign literature data in particular information about its formation growth and functioning in different ecological conditions to outline perspective directions of its influence.

\section{MATERIALS AND METHODS}

A research of 32 literature sources has been made and it has been taken into account that some terminological differences in determining objects of study.

\section{REVIEW AND DISCUSSION}

Oral cavity - ecological complex system in which external factors (biological, individual and social) are closely linked to internal (local immune system, bacterial community on the epithelium of the oral cavity, periodontal metabolites, dentin) are in dynamic equilibrium [1].

Oral cavity microbiocenosis consist of a myriad of bacterial species that coexist in symbiotic harmony with the «host». The microbial population is formed by microor- ganisms with pronounced and moderate association with periodontal diseases.

Microecological changes on the surface of the teeth and the mucouse membrane of the gums associative relationships violations representatives battery oral microflora and enhanced reproduction of opportunistic pathogens that are not inherent in the microbiota of the oral cavity healthy person play an important role in the etiopathogenesis of periodontal tissue diseases [2].

An oral biofilm may consists not only from microorganisms of one species (monoculture) but it may contain two or more different species (polyculture) or planktonic bacteria $[3,4,5,6]$.

The oral microbiota can be in both planktonic form (circulating in the oral fluid) and in the form of colonies that adhere to the surface of organic structures and form a specialized independent self-regulating bacterial ecosystem which ensures the viability and conservation of its organisms microbial populations and also retain the ability to organize associations for coexistence - the so-called oral bacterial biofilm $[7,8,9,10]$.

A dental plaque is a multivariate microbial structure that is formed under liquid media (saliva, oral and gum fluid) and consists of a large number of bacterial morphotypes with the characteristic pattern of bacterial colonies appearing and forming $[11,12,13]$. The habitat provides certain properties inherent in a particular microorganism that were not inherent in the free state.

In the process of tooth plaque formation the following main phases are distinguished [14] (Fig 1):

1. Primary sorption and adhesion of microorganisms from the environment to the surface (pellicle formation, reverse phase) 
2. Fixation - the final attachment of microorganisms with the active release of extracellular polymers to ensure long-term attachment (primary microbial contamination, irreversible phase).

3. Maturation and growth of attached microorganisms - coadhesion of microorganisms, active selection of products of their vital activity, cell division. The resulting biofilm is mature of appropriate shape and size protected from external influences by the polysaccharide matrix.

4. The dispersion of bacteria occurs due to the separation of individual cells from the dental biofilm which subsequently form a new subsidiary colony of microorganisms (secondary microbial insemination).

The basis of the dental plaque is bacterial cells which are located supragingivally. The bacteria in the dental biofilm are clustered forming micro-colonies. Each colony is an independent association with its own individual habitat. The rapid formation of visible layers of microorganisms with extensive bacterial growth is accompanied by the production of a large number of extracellular polymers. At the lower levels of the biofilm is a dense structured attached layer of microorganisms that are linked together in an exopolysaccharide matrix containing a system of water channels that provide metabolic exchange within bacterial associations and exhibit changes in phenotype (growth parameters and expression). The surface layer of the biofilm is free loose amorphous with the ability spread on the surrounding tissues $[16,17]$.

Important characteristics of the bacterial population of a particular anatomical site are the structure and composition of a community of specific microorganisms that due to changes in key environmental parameters will change their quantitative and qualitative characteristics.

In order to ensure biofilm life microenvironment with different $\mathrm{pH}$ levels, partial oxygen pressure and redox potential is important indicating the heterogeneity and ecological heterogeneity of microorganisms.

Communities of biofilm microorganisms in comparison with conventional laboratory cultures acquire new properties that they did not possess in the state of isolated monocultures namely changing the spectrum of gene expression, increasing resistance to environmental factors, antibiotics, phagocytosis, however to preserve cytocycle cooperative behavior of microorganisms that compose it which is coordinated by a bacterial system " quorum sensing » $[18,19,20,21,22]$.

The formation of bacteria composed of biofilms signaling molecules QS - systems that have immunomodulatory properties provides pathogen advantages during the development of chronic inflammation especially in the body immunocompromised patients which in particular are persons resident in the radiation-contaminated areas [23] .

The quantitative and species composition of the microbial flora of the oral cavity of each healthy person is relatively stable as there are a number of factors that ensure its permanence. The most important in maintaining the stability of the microbial composition of the oral cavity is inherent in resident microflora antagonism against pathogenic and opportunistic microorganisms stable microbial group displaces pathogenic agents from the oral cavity.
In the biofilm of the colony of bacteria in comparison with planktonic cultures exhibit special properties: metabolic cooperation primitive system of communication and exchange of genetic information, resistance to phagocytosis, inhibition of neutrophil granulocytes regardless of the presence of specific antibodies and complement resistance. These properties provide the microbiota with qualitative and quantitative advantage [24].

The types of microorganisms found in the biofilm vary not only in different patients but even in one patient in different areas of the oral cavity. In that turn the transmission of periodontal pathogens is carried out horizontally and vertically.

The compensatory properties of resident microflora are not limitless. Under the influence of various factors of exogenous or endogenous nature the dynamic equilibrium between normal and pathogenic flora can be disturbed resulting in a sharp suppression of representatives of normal microflora - developing dysbiosis - qualitative and quantitative changes in resident microflora. The severity of this phenomenon will correspond to the severity of periodontal tissue damage [25].

In the course of an ecological study of the mechanisms of interaction between various bacteria of plaque and the human body five major periodontal microbial complexes were identified consisting of bacteria interconnected in a plaque which depending on the reaction of the macro-organism the presence of nutrients and inter-bacterial competition consortia (Fig. 2).

«Red Complex» (P. gingivalis, B. forsythus, T. denticola) specificity different effects on periodontal tissues and specific clinical manifestations (a significant inflammatory response and bleeding on probing) have a strong proteinase activity that causes rapid progress of destructive processes in periodontists. P. gingivalis - an important component of oral microbiocenosis a successful colonizer of the oral epithelium and the main ethiologic agent of periodontal tissue diseases which causes resorption of the alveolar bone through the formation of dental biofilm and activation of osteoclasts triggering this reaction and local reactions periodontal pathogens.

«Green complex» (A. actinomycetemcomitans, Campylobacter concisus, Eikienella corrodens, Capnocytophaga sputigena). Characteristic forms of diseases with significant destruction of periodontal tissues as well as for a number of diseases with lesions of the oral mucosa and dental hard tissues.

«Orange Complex» (a combination of P. intermedia/ nigrescens, Peptostreptococcus micros, C. rectus + Campylobacter spp.). Is manifested by a rapidly progressive forms of periodontal disease.

There are also «yellow» (Streptococcus mitis, Streptococcus oralis, Streptococcus sanguis) and «purple» systems (Veillonella Parvula, Actinomyces odontolyticus), which may play a protective role by engaging in antagonistic interactions of periodontal pathogens.

The results of a number of foreign and domestic publications allow to distinguish periodontal pathogenic species of the 1-st order («red» complex) and 2-nd order - «orange» and partially «yellow» complex as well as a number of species that are common in the mouth but their the number increases dramatically with the development of periodontal tissue diseases [27, 28, $29,30,31,32]$. 


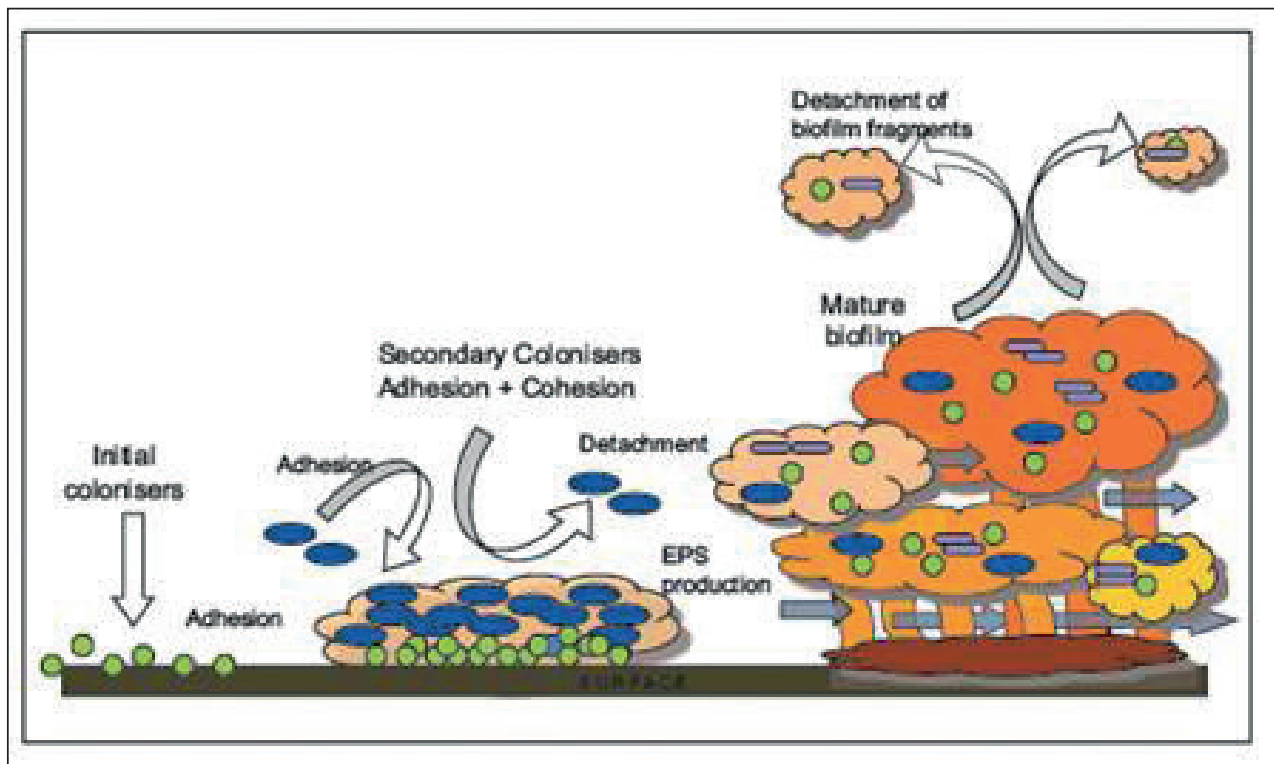

Fig. 1. Plaque formation stages (by Gerbert F. Volf, Tomas M. Hessel, 2014) [15].

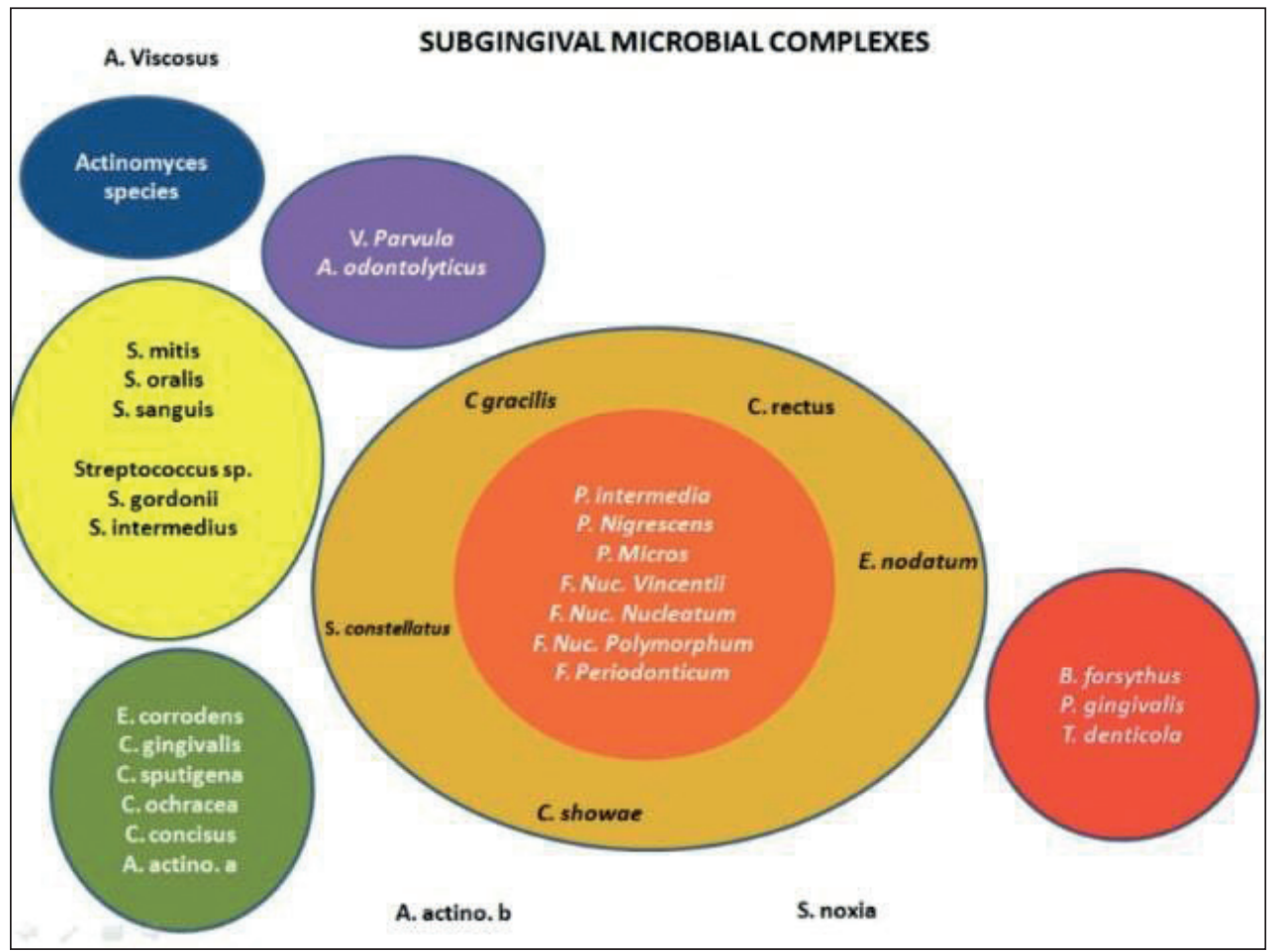

Fig. 2. Graphic representation of microbal complexes (by Socransky, 1988) [26].

The role of microflora in the initiation of periodontal diseases is obvious, but the intensity of the inflammatory response is determined to a large extent by the ability of the macroorganism to resist the impact on it of pathogenic microflora.

\section{CONCLUSIONS}

A detailed analysis of contemporary domestic and foreign literature convinces the need for careful study of oral (dental) biofilms. The trend of modern publications is to cover a complete picture of inflammatory diseases, its etiology and pathogenesis of the oral cavity taking into account the ratio of pathogen load and the macroorganism state. Thus understanding the pathogenetic mechanisms of oral (den- tal) biofilm formation allows the planning of therapeutic measures in clinical pairs of odontology on the basis of evidence-based medicine.

\section{REFERENCES}

1. Zorina 0.A., Kulakov A.A., Grudyanov A.I. Mikrobiocenoz polosti rta v norme i pri vospalitelnyh zabolevaniyah parodonta. Stomatologiya.2011;1:73-78. (In Russian).

2. Zajceva E.M. Parodontit. Sovremennyj viglyad na lechenie. In: Zajceva E. Sankt-Peterburg: 000 «Semaks»;2007,p.3-4. (In Russian).

3. Gostev V.V., Sidorenko S.V. Bacterialnye bioplenki i infekcii. Journal infektologii.2010;2,(3):4-15. (In Russian).

4. Lasa I. Bacterial biofilms and infection. An. Sist. Sanit. Navar. 2005; 28 (2):163-175. 
5. Davies D. Understanding biofilm resistansce to antibacterial agents. Nature reviews. Drug discovery.2003;2:114-122.

6. Keren I. Specialized persister cells and the mechanism of multidrug tolerance in Escherichia coli. J. of Bacteriology.2004;186:8172-8180.

7. Allais Guiseppe. Bioplenka polosti rta. Novoe v stomatologi.2006;4(136):4-5. (In Russian).

8. Costerton J.W., Lewandowski Z., Caldwell D.E. et al. Microbial biofilms. Ann. Rev Microbiol.1995;49:711-745.

9. Darveau R.P., Tanner A., Page R.C. The microbial challenge in periodontology. Periodontology 2000.1997;14:12-32.

10. Gera C., Srivastava S. Quorum-sensing: the phenomenon of microbial communication. Current Science.2006;90(5):666-677.

11. Tsarev V.N., Ippolitov E.V. Periodontopatogenic bacteria — risk indicators of periodontitis emergence and development (Part II). International Dental Review.2011;4:4-7. (In Russian).

12. Brandtzaeg P. Homeostatic impact of indigenous microbiota and secretory immunity. Beneficial microbes.2010;1(3):211-227.https:// doi.org/10.3920/BM2010.0009

13. Aas T.A., Paster B.J., Stokes L.N. Defining the normal bacterial flora of the oral cavity. J. Clin Microbiol.2005;43(11):57215732.

14. Donald R.M., Costerton J.W. Biofilm: survival mechanisms of clinically relevant microorganisms. Clin Microbiol Rev.2002;5(2):167193.

15. Volf Gerbert F. Parodontologiya. Gigienicheskie aspekty. MEDpressinform;2014,p.36. (In Russian).

16. Wolfaardt G.M., Lawrence J.R., Robarts R.D. In situ characterization of biofilm exopolymers involved in the accumulation of chlorinated organics. Microb Ecol.1998;35:213-223.

17. John G.T., Lindsay M.S., Nakaishi B.S. Managing the complexity of a dynamic biofilm . J. Am Dent Assoc.2008;139(3):252.

18. Ilina T.S., Romanova Yu.M., Ginzburg A.L. Bioplenki kak sposob sushestvovaniya bakterij v okruzhayushej brede i organizme hozyaina: fenomen, geneticheskij kontrol i sistemy regulyacii. Genetika.2004;40(11):1-12. (In Russian).

19. Melnikov V.G. Poverhnostnye struktury grampozitivnyh bakterij v mezhkletochnom vzaimodejstvii i plenkoobrazovanii. Zhurnal mikrobiologii, epidemiologii i immunobiologii. 2010;2:119-123. (In Russian).

20. O'Toole G., Kaplan H.B., Kolter R. Biofilm formation as microbial development. Ann. Rev. Microbiol.2000;54:49-79.

21. Saye D.E. Recurring and antimicrobial-resistant infections: considering the potential role of biofilms in clinical practice. Ostomy Wound Manage.2007;53:46-62.

22. Stoodley P., Sauer K., Davities D.G. et al. Biofilms as complex differentiated communities. Ann. Rev. Microbiol.2002;56:187-209.

23. Hooi D.S., Bycroft B.W., Chabra S.R. et al. Differential immune modulatory activity of Pseudomonas aeruginosa quorum-sensing signal molecules. Infect. Immun.2004;72:6463-6470.

24. Slots J., Jorgensen M.G. Effective, safe, practical and affordable periodontal therapy: where are we going, and are we there yet. Periodontology 2000.2002;28(1):298-312.

25. Grudyanov A.I. Metody diagnostiki vospalitelnyh zabolevanij parodonta. Rukovodstvo dlya vrachej. In: Grudyanov Al, Zorina 0A. M.: 000 «Medicinskoe informacionnoe agentstv0».2009,p. 52-54. (In Russian).

26. Hans-Peter M. Parodontologiya. GalDent.2014, p.42. (In Russian).
27. Peyyala R., Kirakodu S.S., Novak K.F. et al. Oral microbial biofilm stimulation of epithelial cell responses. Cytokine.2012;58(1):65-72. https://doi.org/10.1016/j.cyt0.2011.12.016

28. Guggenheim B., Gmür R., Galicia J.C. In vitro modeling of hostparasite interactions: the "subgingival» biofilm challenge of primary human epithelial cells. Microbiology.2009;9:280. https://doi. org/10.1186/1471-2180-9-280

29. Stecyk M.0., Kostenko S.B. Mikroekologicheskij i immunnyj gomeostaz u lic, postoyanno prozhivayushih na radiacionno-zagryaznennoj territorii. Science progress in European countries: new concepts and modern solutions»: Abstract books of 6th International Scientific Conference (April 19, 2019). - Stuttgart, Germany,2019:391-396. (In Russian).

30. Peyyala R., Ebersole J.L. Multispecies Biofilms and Host Responses: «Discriminating the Trees from the Forest». Cytokine.2013;61(1):15-25.

31. Brandtzaeg P. Homeostatic impact of indigenous microbiota and secretory immunity. Beneficial microbes.2010;1(3):211-227. https:// doi.org/10.3920/BM2010.0009

32. Darveau R.P. Periodontitis: a polymicrobial disruption of host homeostasis. Nature Reviews Microbiology. 2010;8:481-490.

This article was written as part of the research work of the department: "Clinical and laboratory research of modern dental technologies and expert evaluation of treatment methods quality parameter», 0118U004526. Scientific leader: PhD Kostenko Svitlana Borysivna.

\section{ORCID and contributionship:}

Maria O. Stetsyk: 0000-0002-4586-5177 D

Andriy O. Stetsyk: 0000-0003-1300-4054 ${ }^{B}$

Natalia I. Zhero: 0000-0002-8083-9310 ${ }^{\mathrm{A}}$

Eugene Y. Kostenko: 0000-0002-3997-2371 ${ }^{\mathrm{F}}$

Svetlana B. Kostenko: 0000-0002-4590-2863 ${ }^{E}$

Ilya D. Pirchak: 0000-0002-0719-6793 ${ }^{\mathrm{C}}$

\section{Conflict of interest:}

The Authors declare no conflict of interest.

\section{CORRESPONDING AUTHOR Maria 0. Stetsyk \\ Uzhhorod National University \\ 16a Universitetska St., 88000 Uzhhorod, Ukraine \\ tel: +380976641993 \\ e-mail: mariia.stetsyk@uzhnu.edu.ua}

Received: 14.09 .2019

Accepted: 03.06 .2020
A - Work concept and design, B - Data collection and analysis, C - Responsibility for statistical analysis, D-Writing the article, $\mathbf{E}$-Critical review, $\mathbf{F}$ - Final approval of the article 